\title{
THE SPATIAL STUDY OF HEALTH CONDITION OF SOCIETY TOWARDS INCOME GRADE IN PRAMBANAN, KLATEN REGENCY
}

\author{
Ayu Fatonah ${ }^{1}$, Fitria Febri Setiyani ${ }^{2}$, Hafiz Winardany ${ }^{3}$, Samidu $^{4}$, Bagas Anindra \\ Murdiansyah $^{5}$, Fitri Nur Aini ${ }^{6}$ \\ 1,2,3,4,5,6 Department of Geography Education, Muhammadiyah University of Surakarta \\ Email : ayufatonah06@gmail.com
}

Received: 25 June 2018/Revised: 18 July 2018/Accepted: 20 July 2018/Published online: 28 August 2018

\begin{abstract}
Health is the most important aspect of the human being life. A good health will affect other aspects, one of which will affect the economic aspect of the income earned by individuals. The purpose of this research is to know the correlation between the health condition and income of society in Prambanan Sub-district. This research uses quantitative descriptive research, with the research variables such as health data and income data. The sample in this study amounted to 2,235 respondents from 16 Villages in Prambanan Subdistrict, Klaten. The Data Collection Method used in this research are an interview, observation, and questionnaire with the data analysis technique is a quantitative descriptive analysis which is nonstatistical analysis with a frequency table. The results show that there is not a significant correlation between health and income. Pereng Village has an average of "High" income with the population average monthly income> Rp. $1.500 .000,00$ of 52.04\% but has a health condition in the "Medium" level.RandusariVillage has a health condition in the "Medium" level whereas Randusari Village has average "Low" income with a population withanaverage income per month $<$ Rp. $500.000,00$ for $44,44 \%$.
\end{abstract}

Keywords: Health Conditions, Income

\section{Introduction}

Inequality and equity are commonly discussed in discussing economic growth and development. According to Seers, economic development is ideal if three main goals are achieved: increased capita income, decreasing inequality, and poverty reduction (Lutfi Muta'ali, 2015: 142). Based on BPS data, the phenomenon of poverty and inequality in Indonesia has a percentage of $7 \%$ yearly, which makes one of the few countries able to achieve relatively high growth rate (Sudarlan, 2015). Soetatwo Hadiwigeno and A. Pakpahan stated that the poverty and inequality of income distribution are caused by inequality in natural resources, human resources, and infrastructures, including accessibility so that people have limits in making choices that hamper their development (Lutfi Muta'ali, 2015: 142).

Sukirno stated that the growth and economic development of the region are not always followed by equality of economic development and even distribution of income (Lutfi 
Muta'ali, 2015: 153). The high rate of economic growth is not followed by improvements in the distribution of income, so the pattern of inequality in Indonesia is not much decreased. The achievement of high economic growth achieved by various regions does not guarantee the creation of equal distribution of income among individuals, and often economic growth is followed by inequality in development. The most obvious inequality is the income aspect that gives rise to the rich and the poor (Mauliddiyah, 2014 in Handika, 2017).

Research conducted by Budiantoro Hartono showing that inequality of economic development between regions in Central Java province is calculated using index Williamson during the period 1981-2005 shows the inequality increases. Calculation based on Theil Entropy noted that as large provinces in Indonesia classified into classes of high economic inequality (based on the value of the median of 34 provinces - to). Based on research done by Abdi Susilo (2017), the results of the calculation of the index showed the level of income inequality Williamson averaged 0.6 then district/town in Central Java Province are included in the categories is quite high because the index the above figure shows Williamson 0.5. It is in line with the research conducted by Hendika Alviana (2017) which shows the county is Klaten Regency had a rate of growth with an average of $11.37 \%$ is included in the category of being.

In the period of the year 1999-2009 observations are analyzed by using the index and the Theil entropy Williamson, then can be noted that the level of inequality that occurred in Klaten Regency has a value smaller or the more equitable and stable (Andi, 2012).In the year 2015 Index Williamson Klaten 0.045 figures showedthat income inequality results in Klaten Regency arelow so that the construction of the area can be said to be evenly because IW is approaching 0 (Abdi, 2017). The results of the Susenas year 2015, Ratio of income distribution Gini inhabitants in Klaten Regency recorded of 0.35 which is included in levels of inequality are (BPS, 2016). This reflects that the average income of a resident of Klaten received from different income groups still evenly.

Revenue generated by the population will affect some aspects of people's lives, one of which, namely the aspects of health in the community. Based on research conducted by Ismail M (2013), shows that there is significant influence between the income levels of families with nutritional status on toddlers. Instead, health will be one of the factors that affect the level of income generated by an individual. Ananta and Hatmadjdi stated that the high low quality of human resources will be determined by the status of the health, education and income level per capita (Karma Wisana, 2001). At the level of individuals or families, health is a foundation for work productivity and capacity for learning in all schools because 
of physical and mental health can make someone more energetic, powerful, productive so that it can earn higher (Arum, 2009).

One of the indicators in describing the condition of public health can be seen from the figures for life expectancy. Life expectancy in Klaten Regency showed figures amounted to 76.59 years in 2016, this figure has increased compared to the year 2015 of 76.55 years (HDI of Klaten, 2016). Health problems in Klaten the most dominant among others: Demam Berdarah Dengue (DBD) and diarrhea (Health Profil of Klaten Regency, 2016).

Prambanan sub-district is one sub-district in Klaten Regency were vulnerable to health problems, such as Demam Berdarah Dengue (DBD). Demam Berdarah Dengue $(D B D)$ happened in Prambanan in 2017 i.e. as many as 105 cases in 16 villages in Kecamatan Prambanan (Achmad Fadhilah, 2017). Given the Prambanan Sub-district is one of the tourist destinations then the health problems will affect the condition of society in Prambanan. Based on the background, the author is interested in conducting research with the title "Spatial StudyHealth Condition of Society towards Income Grade inPrambanan, Klaten Regency".

\section{The Methods}

This research was held in the district of Prambanan Sub-district is one contained in Klaten Regency, Central Java. This research was conducted in 16 villages in the Sub-District of Prambanan, there are Cucukan, Kemudo, Brajan, Joho, Sanggarahan, Kebondalem Lor, Bugisan, Tlogo, Kotesan, Randusari, Sengon, Taji, Kokosan, Geneng, Pereng, and Kebondalem Kidul.

Table 1 Population and Sample of the study

\begin{tabular}{lcc}
\hline \multicolumn{1}{c}{ Village } & Population & Sample \\
\hline Cucukan & 1.066 & 139 \\
Kemudo & 1.609 & 208 \\
Brajan & 944 & 123 \\
Joho & 1.511 & 142 \\
Sanggrahan & 1.253 & 169 \\
Tlogo & 1.770 & 136 \\
Bugisan & 1.216 & 154 \\
Kebondalem Lor & 2.395 & 180 \\
Kotesan & 697 & 132 \\
Randusari & 1.514 & 110 \\
Sengon & 1.715 & 115 \\
Taji & 1.009 & 126 \\
Kokosan & 894 & 123 \\
Geneng & 1.029 & 157 \\
Pereng & 836 & 99 \\
Kebondalem Kidul & 1.471 & 122 \\
\multicolumn{1}{c}{ Sum } & $\mathbf{2 0 . 9 2 9}$ & $\mathbf{2 2 3 5}$ \\
\hline
\end{tabular}

Source: Researcher, 2018 
The number of samples taken is the head oftheresearchfamilyin Prambanan with 2235 samples from 20,929 population. Determination of the number of samples by using the formula of Solvin. The smallest amount of sample that is 99 samples contained in the Pereng Village and the largest that is 208 samples contained in the Kemudo village. Retrieval technique of sampling with random sampling.

Type of this research is quantitative descriptive research with data in the form of variable data onthehealthcondition and the revenue data found in Prambanan. Health data are used i.e. regularity in health checks, the frequency of checks, the utilization of health clinics, septictank, and water resource ownership. Engineering data collection using the quisoner i.e. the data in the form of health conditions and people's income in Prambanan Additionally data collecting was done through interviews and observations. The method of this research is quantitative descriptive analysis with primary data about the condition and health of the revenue taken in the field. Quantitative descriptive data analysis is the analysis of data in a manner described or describe the data that has been collected (Febriyana, et al, 2017). Presentation of data through tables, graphs, pie charts and percentage. Data about the health and income obtained by way of finding the mean of each village that located in Kecamatan Prambanan which was later modified in the form of a percentage. The scale of the public health conditions in Prambanan can be seen in table 2.2.

Tabel 2. Level of Public Health in Kecamatan Prambanan

\begin{tabular}{ccc}
\hline No & Level & Score \\
\hline 1 & Low & $0-33,33$ \\
2 & Medium & $33,34-66,67$ \\
3 & High & $66,68-100$ \\
\hline \multicolumn{2}{l}{ Source:Researcher, 2018}
\end{tabular}

\section{Results and Discussion}

To know the relationship between Public Health Conditions and Community Income, researcher use 5 indicators, that is :

\subsection{Income and Continuity of Health Check}

Based on figure 3.1, it can be seen that Randusari Village has a low-income level,mostof the people in Randusari Village have income < Rp.500.000,00 however,the regularity of health check conducted by the community included in the medium level.This shows that people in Randusari Village already have a good level of health-related understanding of health check.Randusari Village community in conducting health check 
included in medium level because of accessibility to health center easy and society utilize health center in addition to treatment also to conduct routine health check.

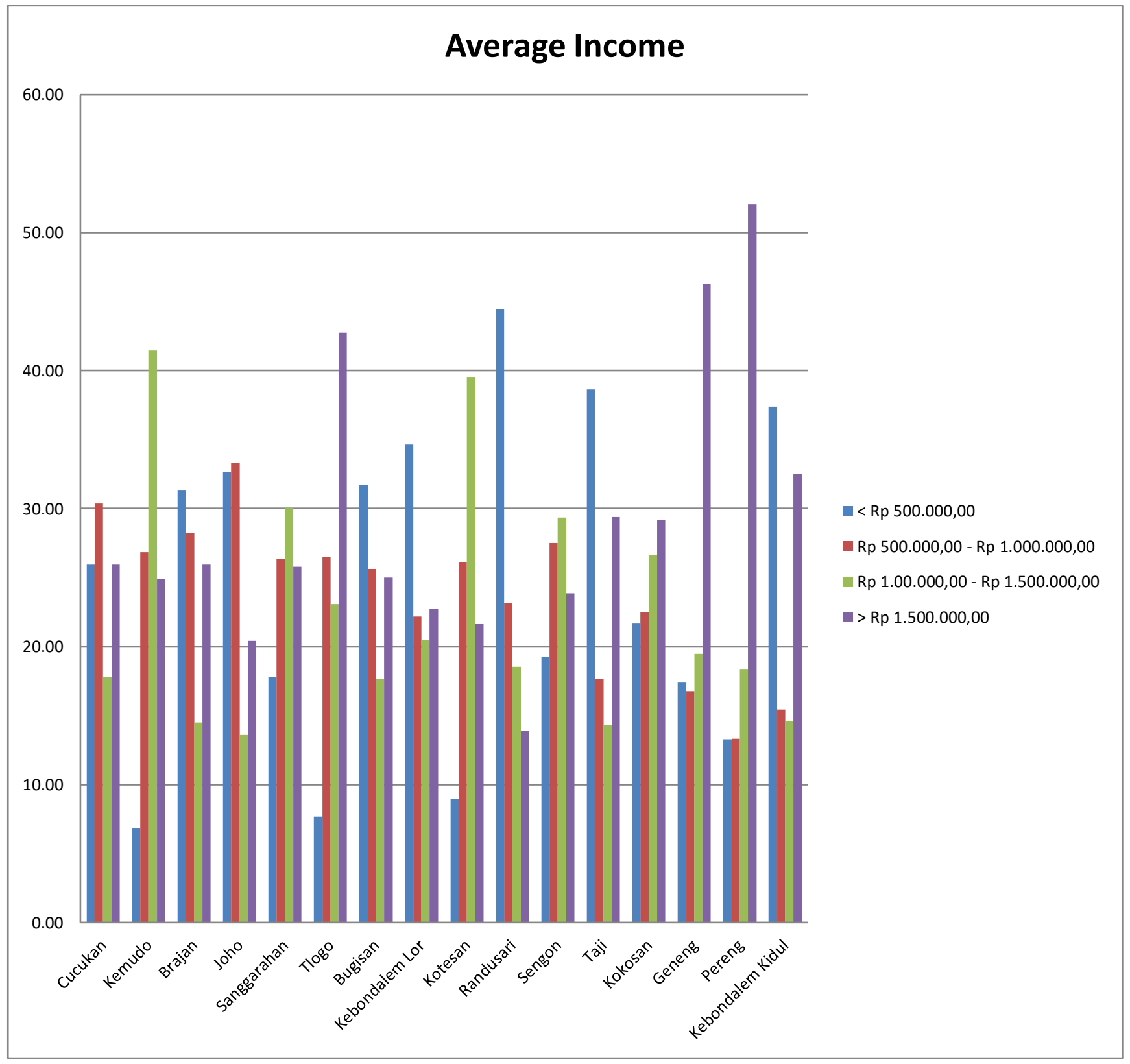

Figure 1. Graph of Average Income Prambanan Sub-district Source:Researcher, 2018 


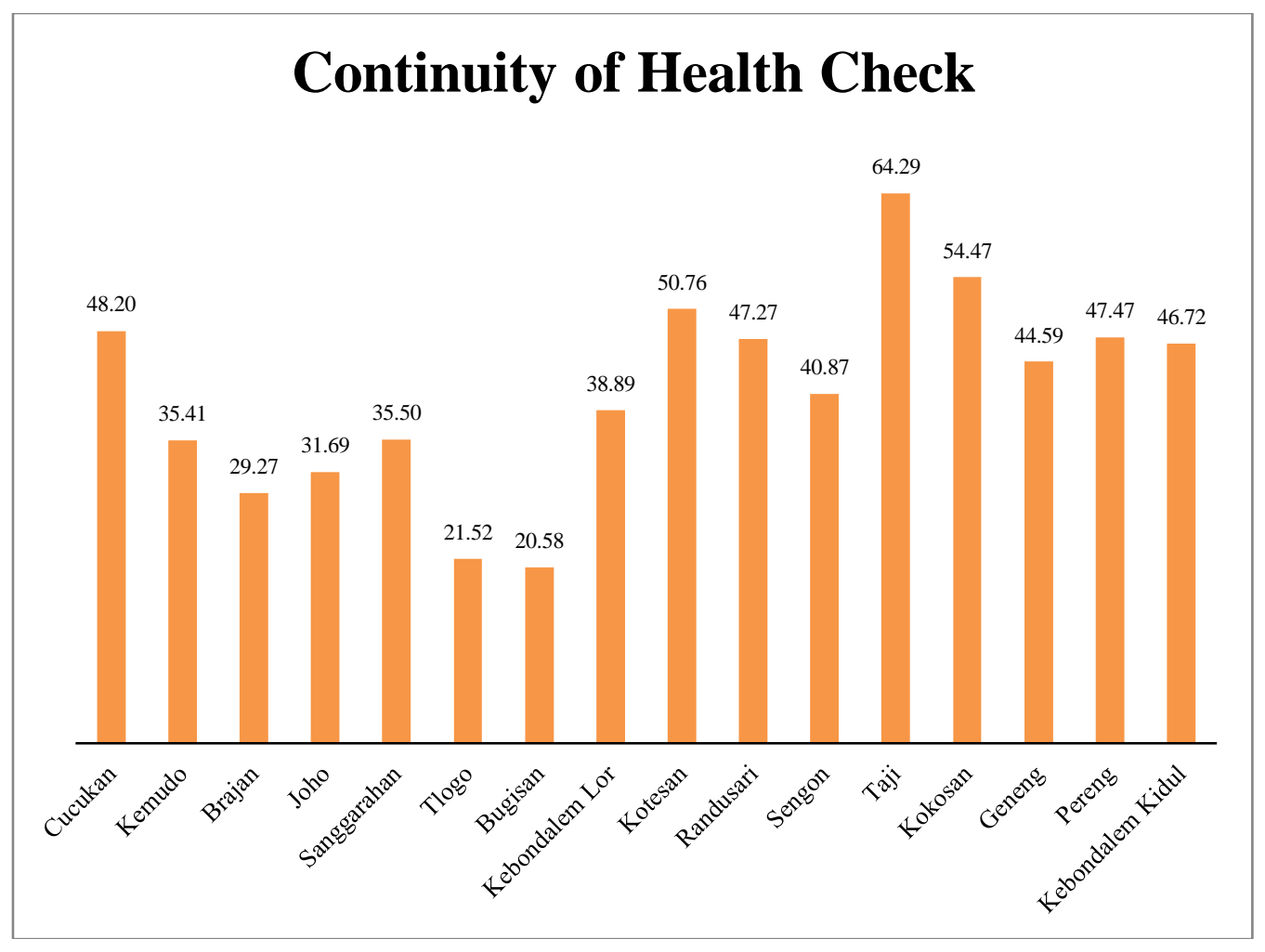

Figure 2. Graph of Health Check of Prambanan Sub-district Source:Researcher, 2018

Table 3. Level Continuity Health Check

\begin{tabular}{llll}
\hline No & Level & \multicolumn{1}{c}{ Score } & \multicolumn{1}{c}{ Village } \\
\hline 1 & Low & $0-33,33$ & Brajan, Joho, Tlogo, Bugisan \\
2 & Medium & $33,34-66,67$ & $\begin{array}{l}\text { Cucukan, Kemudo, Sanggrahan, } \\
\text { Kebondalem Lor, Kotesan, } \\
\end{array}$ \\
& & & $\begin{array}{l}\text { Randusari, Sengon, Taji, Kokosan, } \\
\text { Geneng, Pereng dan Kebondalem }\end{array}$ \\
& & & Kidul \\
3 & High & $66,68-100$ & \\
\hline
\end{tabular}

Source: Researcher, 2018

Pereng Village is a village that has a high-income level because the majority of the people have average income monthly more than Rp.1.500.000,00 but in terms of health check Pereng Village included in the medium level.The percentage of health check between Randusari Village and Pereng Village have not significantly different.The distance between the Village and local government clinic is not far away, the majority of 
Pereng Villagecommunity utilize local government clinic or hospitals when the people do medication and just a few people who do a regular health check.

Based on figure 3.2, Taji Village is the village that has the highest percentage among other Villages.Taji Village is a Village whose majority community routinely performs health check so that Taji Villagecommunity already have a good level of understanding about health, where the majority of Taji Village are people with average monthly income less than Rp.500.000,00.This shows that there is no relationship between one of the indicators of the health condition of the community i.e. Continuity of health Check with the income levels of people in Prambanan, Klaten Sub-district. These results are in accordance with research conducted by Yuhendri (2013), that shows that there is no relationship between economic growth with public health conditions in West Sumatra.

\subsection{Income and Frequency of Health Check}

Based on figure 3.3,Pereng Village has a frequency in performing the health check as the major is doing 1-2 times in one year.Pereng Village is a Village whose majority of the community has an average income in one month that is more than Rp.1.500.000,00.Based on figure 3.1, Randusari Village is a Village where the majority of people have low income and frequency of public health check as big as 1-2 times a year.Pereng and Randusari Village share the same frequency of health check 1-2 times per year,but Pereng Village has a lower percentage compared to Randusari Village.This shows that Pereng Village health level is lower than Randusari Village, so that majority of Randusari Village communitydo not understand in maintaining health.Based on that explanation may be aware that there is no relationship between the frequencyof health check with the income level in the society. This research fits with research conducted by Syamsurijal (2008) with the result that the health condition of the bad influence towards increasing income per-capita in South Sumatra. 


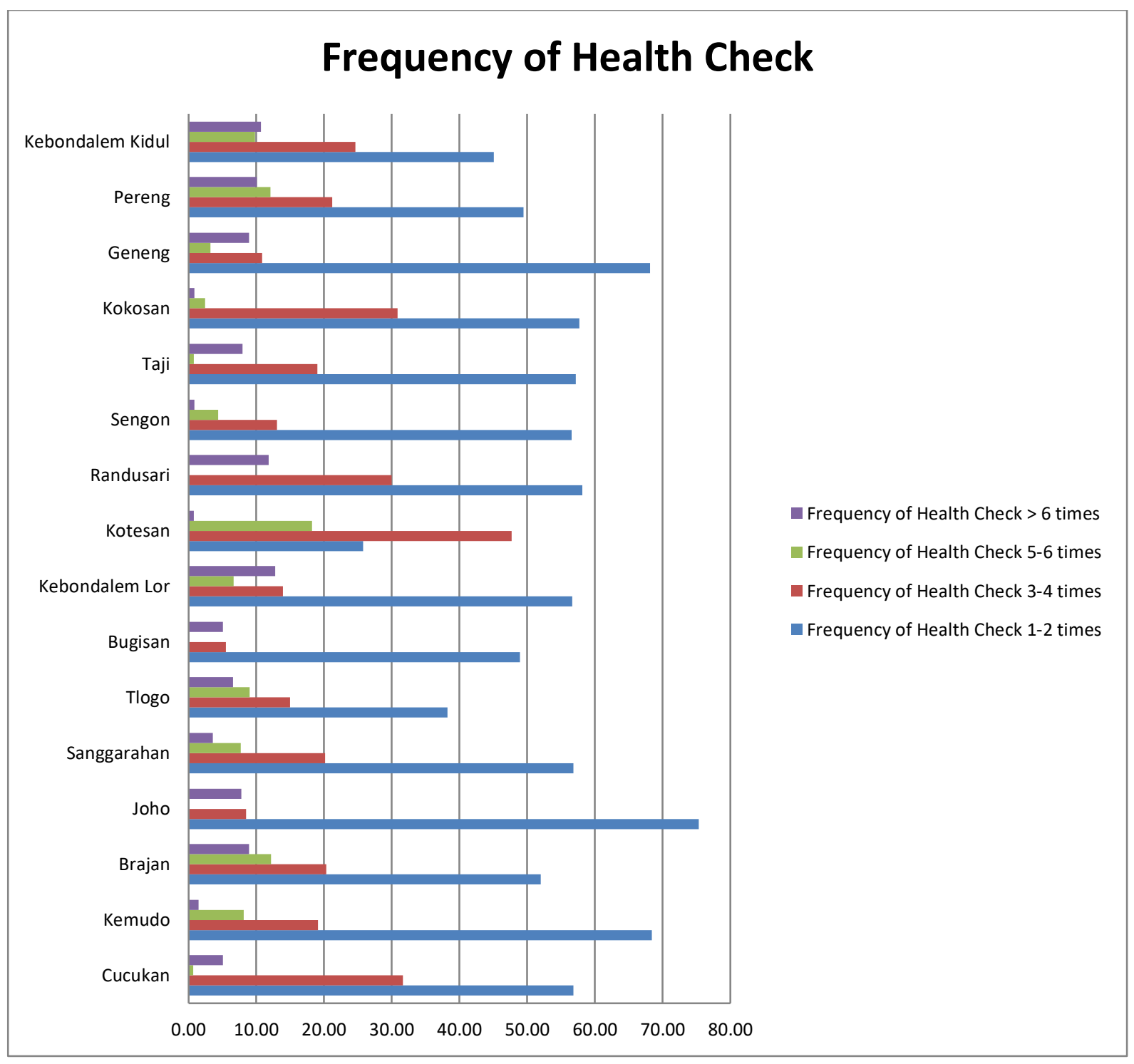

Figure 3. Frequency of Health Check

Source: Researcher, 2018

\subsection{Income and Utilization of Health Center}

Based on figure 3.1 Pereng Village is a Village whose majority of the community has a high-income level and Randusari Village is the Village that most of the people have a low-income level. 


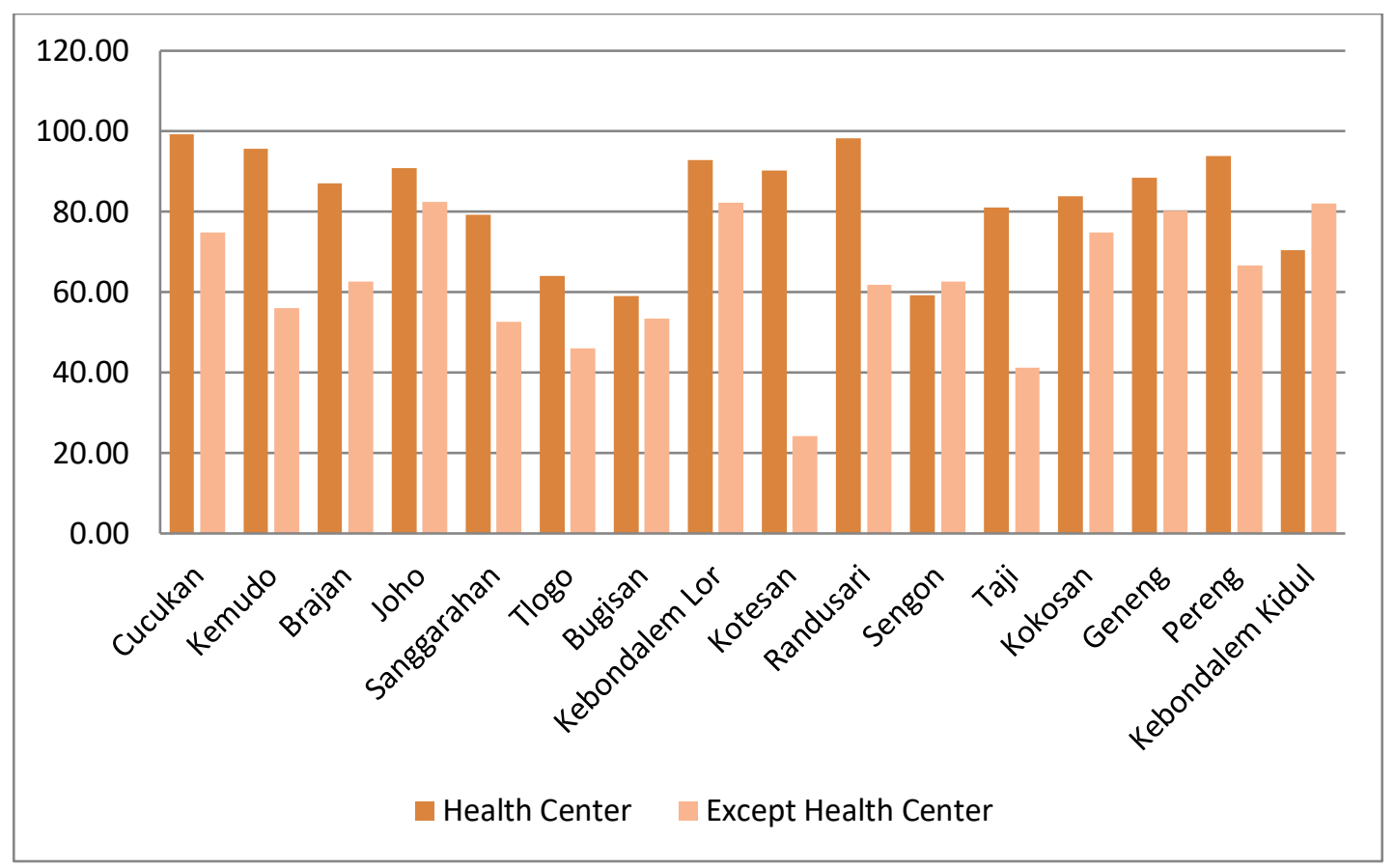

Figure 3.4 Graph of Utilization level of Health Center of Prambanan Sub-district Source: Researcher,2018

Table 4. Level of Health center Utilization

\begin{tabular}{cccl}
\hline No & Level & \multicolumn{1}{c}{ Score } & \multicolumn{1}{c}{ Village } \\
\hline 1 & Low & $0-33,33$ & - \\
2 & Medium & $33,34-66,67$ & Tlogo, Bugisan, Sengon \\
3 & High & $66,68-100$ & $\begin{array}{l}\text { Cucukan, Kemudo, Brajan, Joho, } \\
\text { Sanggrahan, Kebondalem Lor, } \\
\end{array}$ \\
& & Kotesan, Randusari, , Taji, Kokosan, \\
& & Geneng, Pereng dan Kebondalem \\
& & Kidul \\
\hline
\end{tabular}

Source: Researcher, 2018

The Randusari and Pereng Villages in utilizing health center are at a high level,but the utilization of the health center in Randusari Village is higher than that of PerengVillage.The percentage difference between the utilization rate between Randusari Village and Pereng Village is $4.24 \%$. This can know that Randusari community whose community mostly have low income is fewer Rp.500.000,00 prefer to take advantage ofthehealth center more affordable compared to the cost in hospital or clinic. 
Ayu Fatonah, et al / GEOSI Vol. 3 No. 2 (2018) 52-66

Table 5. Utilization Rate Other than Health center

\begin{tabular}{|c|c|c|c|}
\hline No & Level & Score & Village \\
\hline 1 & Low & $0-33,33$ & Kotesan \\
\hline 2 & Medium & $\begin{array}{l}33,34- \\
66,67\end{array}$ & $\begin{array}{l}\text { Kemudo, Brajan, Sanggrahan, } \\
\text { Tlogo, Bugisan, Randusari, } \\
\text { Sengon, Taji, Pereng }\end{array}$ \\
\hline 3 & High & $66,68-100$ & $\begin{array}{l}\text { Cucukan, Joho, Kebondalem } \\
\text { Lor, Kokosan, Geneng, dan } \\
\text { Kebondalem Kidul }\end{array}$ \\
\hline
\end{tabular}

Source: Researcher, 2018

Pereng Villagecommunity in utilizing health facilities in addition to health centers such as clinics or hospital are included in a high level,while for the Randusari Village included in the Medium level.This shows that the majority of Pereng Village community have high income is more than Rp.1,500.000,00 also take advantage of health facilities such as clinics or hospitals in a high level because the people have a high income as well.This shows that there is no relationship between the Utilization of Health Center with the income levels of people in Prambanan, Klaten Sub-district. These results are in accordance with research conducted by Yuhendri (2013) that shows that there is no relationship between economic growth with public health conditions in West Sumatra.

\subsection{Income and Ownership Septictank}

Based on Figure 3.1, it can be seen that Randusari Village has a low-income level,most of the people in Randusari Village have income <Rp.500.000,00 however,90\% of people have their own septictank and are included in the high level.This demonstrates that people in RandusariVillage already have a good level of health-related understanding.Pereng Village is a village that has high-income level because the majority of the people have average income monthly more than Rp.1.500.000,00 with the income the majority of the people have septictank own only $2.20 \%$ of people who do not have septictank own.This shows that people in Pereng Village have a high awareness of the importance of maintaining environmental health and personal health.The percentage of ownership of septictank in Randusari Village and Pereng Village has a difference that is not too far that is equal to $7.98 \%$, Pereng Village is higher than Randusari Village.This is 
proportional to the average income in Pereng Village which is higher than Randusari Village.Based on that explanation may be aware that there is no relationship between ownership of septic tank which is one indicator that is used to find out the condition of public health with income levels in the community Prambanan. This research fits with research conducted by Syamsurijal (2008) with the result that the health condition of the bad influence towards increasing income per-capita in South Sumatra.

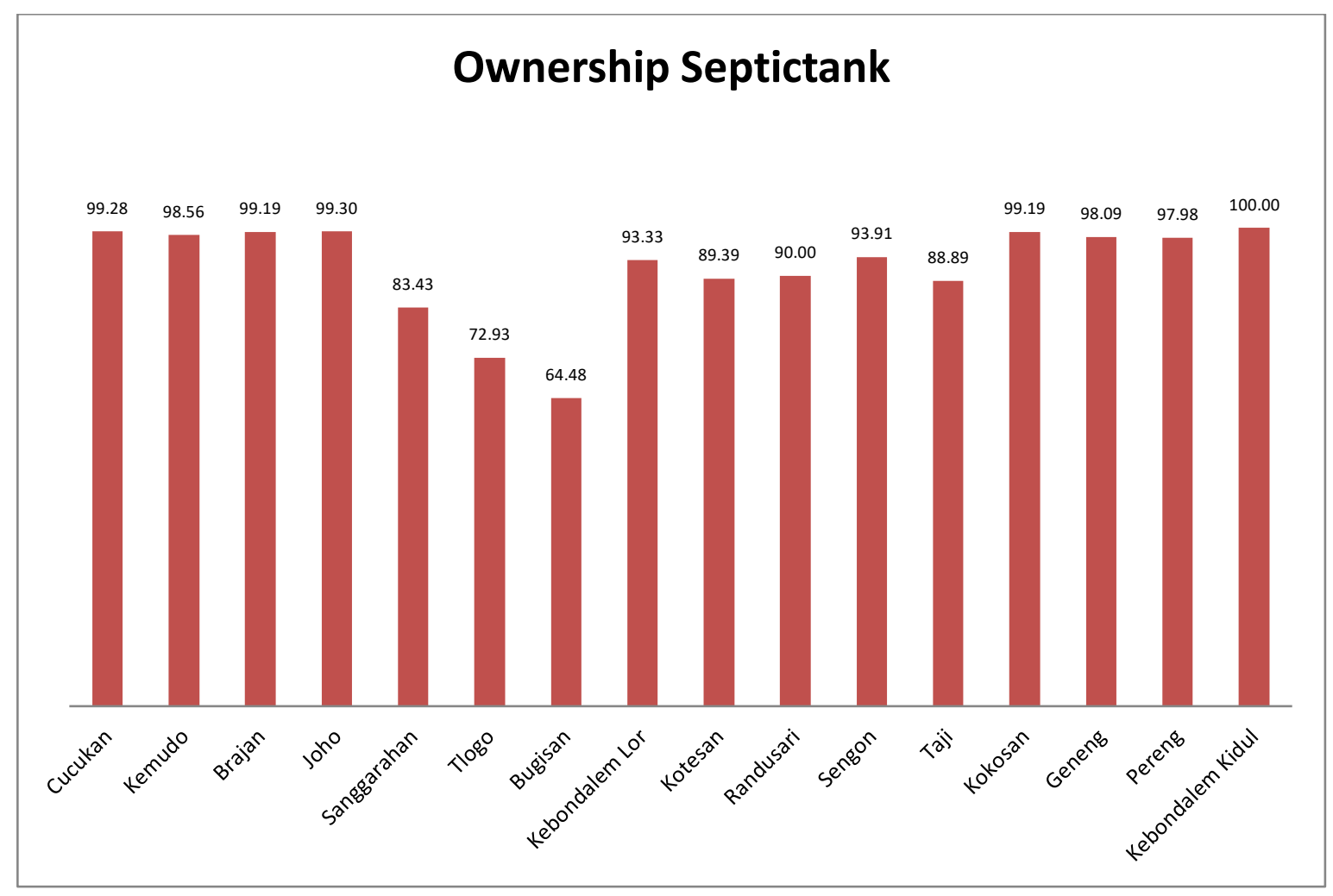

Figure 3.5 Graph of Ownership Septictank

Source: Researcher, 2018

\subsection{Income and Water Resources}

Based on figure 3.6, both Randusari Villagehas the lowest average income and Pereng Village which has the highest average income equally utilizes the well water used in daily life.This shows that the need for understanding to the community about the water resources that are suitable for use because not all well water is suitable for use is mainly used as drinking water. This shows that there is no relationship between community health condition with an indicator of use of water sources with the people's income level in Prambanan, Klaten. These results are in accordance with research conducted by Yuhendri 
(2013) that shows that there is no relationship between economic growth with public health conditions in West Sumatra

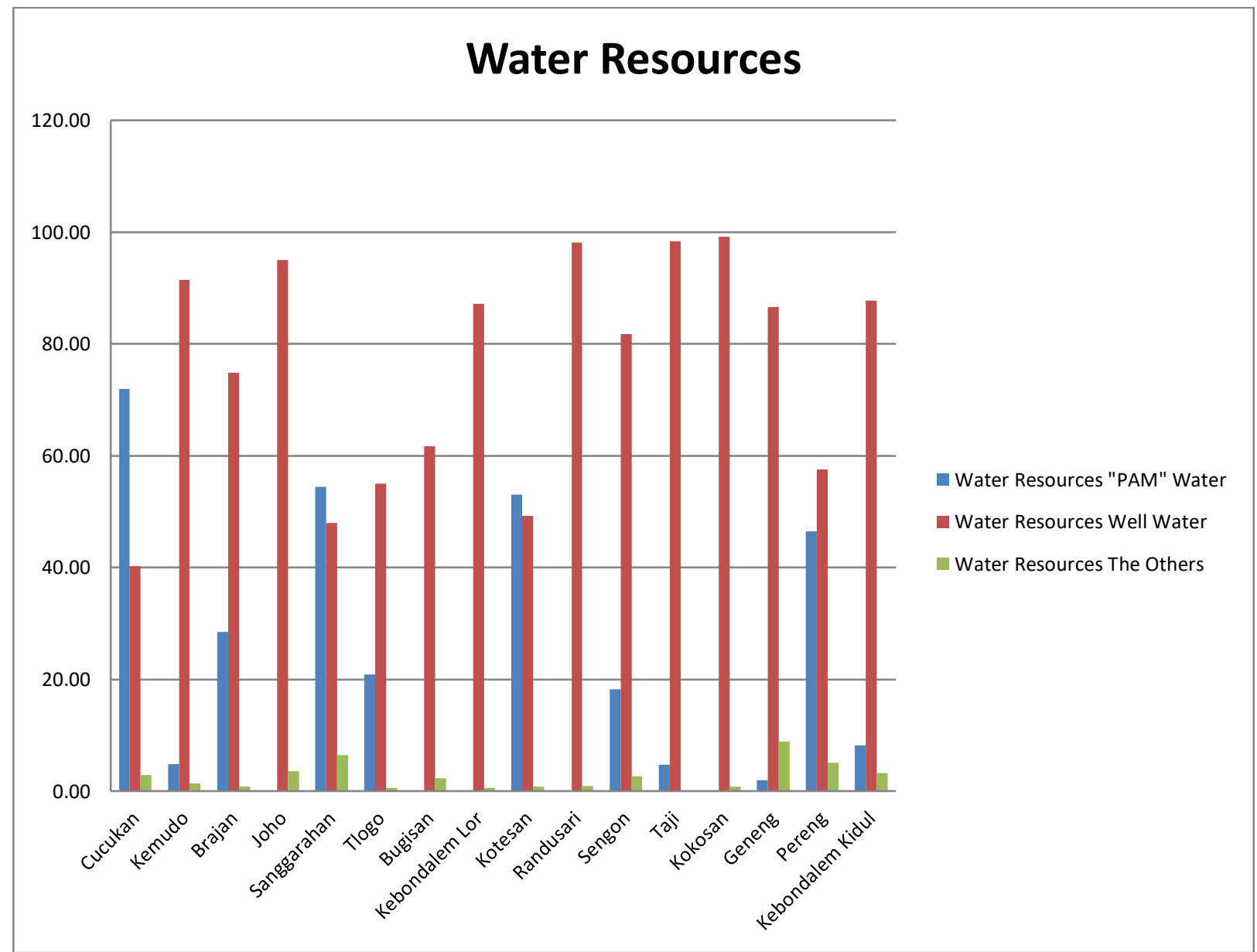

Figure 3.6 Graph of Prambanan Sub-district Water Resources Source: Researcher, 2018

Based on Figure 3.7and 3.8 can be known the level of public health andincome in Prambanan, Klaten.Joho Village, Kebondalem Lor Village, and Geneng Village are a village has a high level of health conditions while Kotesan Village and Tlogo Village are a village which is included in the low categories. The lowest average income in the Prambanan Sub-District is in Randusari Village, while Pereng village is a village that has average income communities included in the categories high 
Ayu Fatonah, et al / GEOSI Vol. 3 No. 2 (2018) 52-66
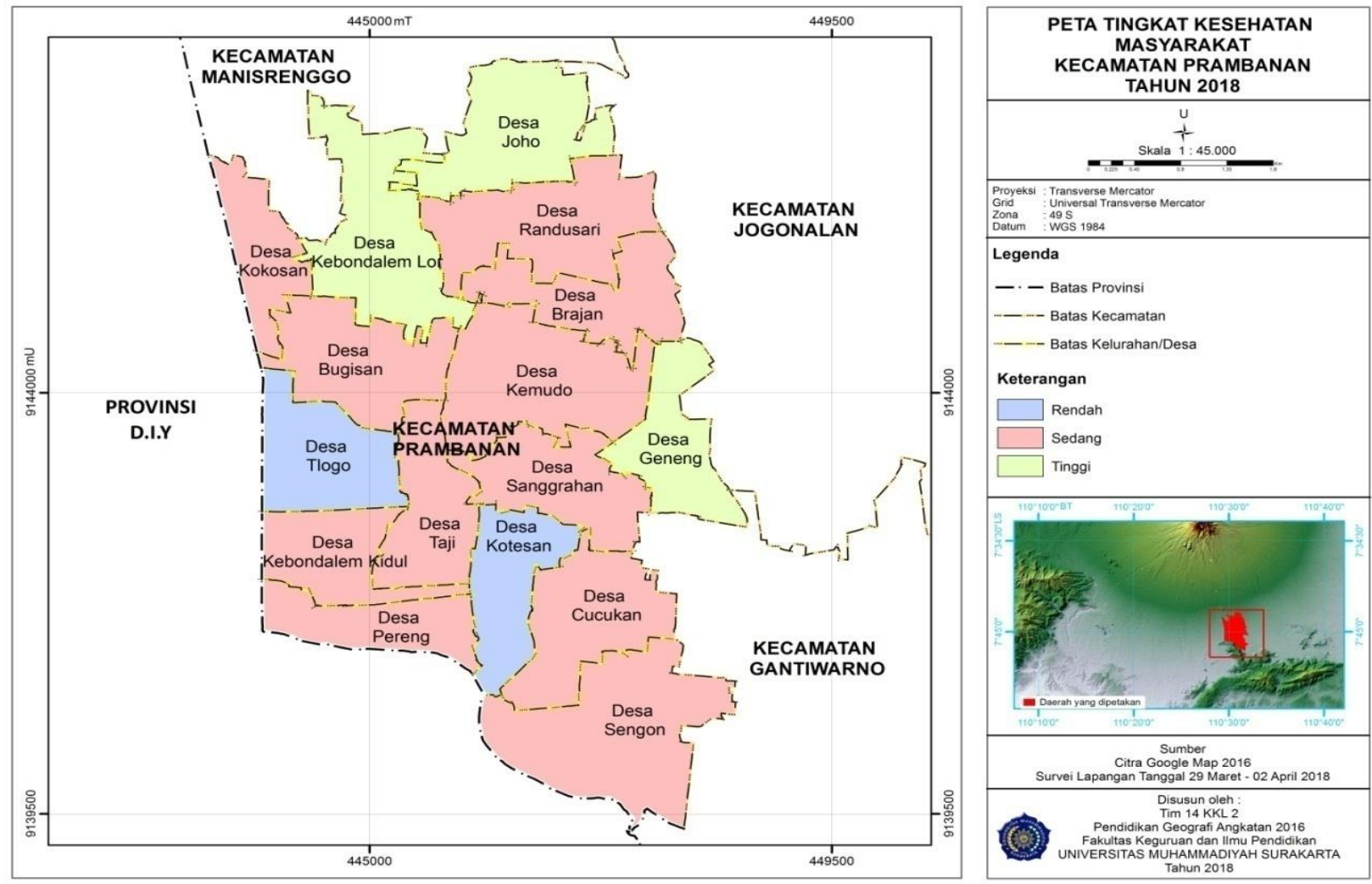

Figure 3.7Map of Level Health Conditions

Source: Researcher, 2018
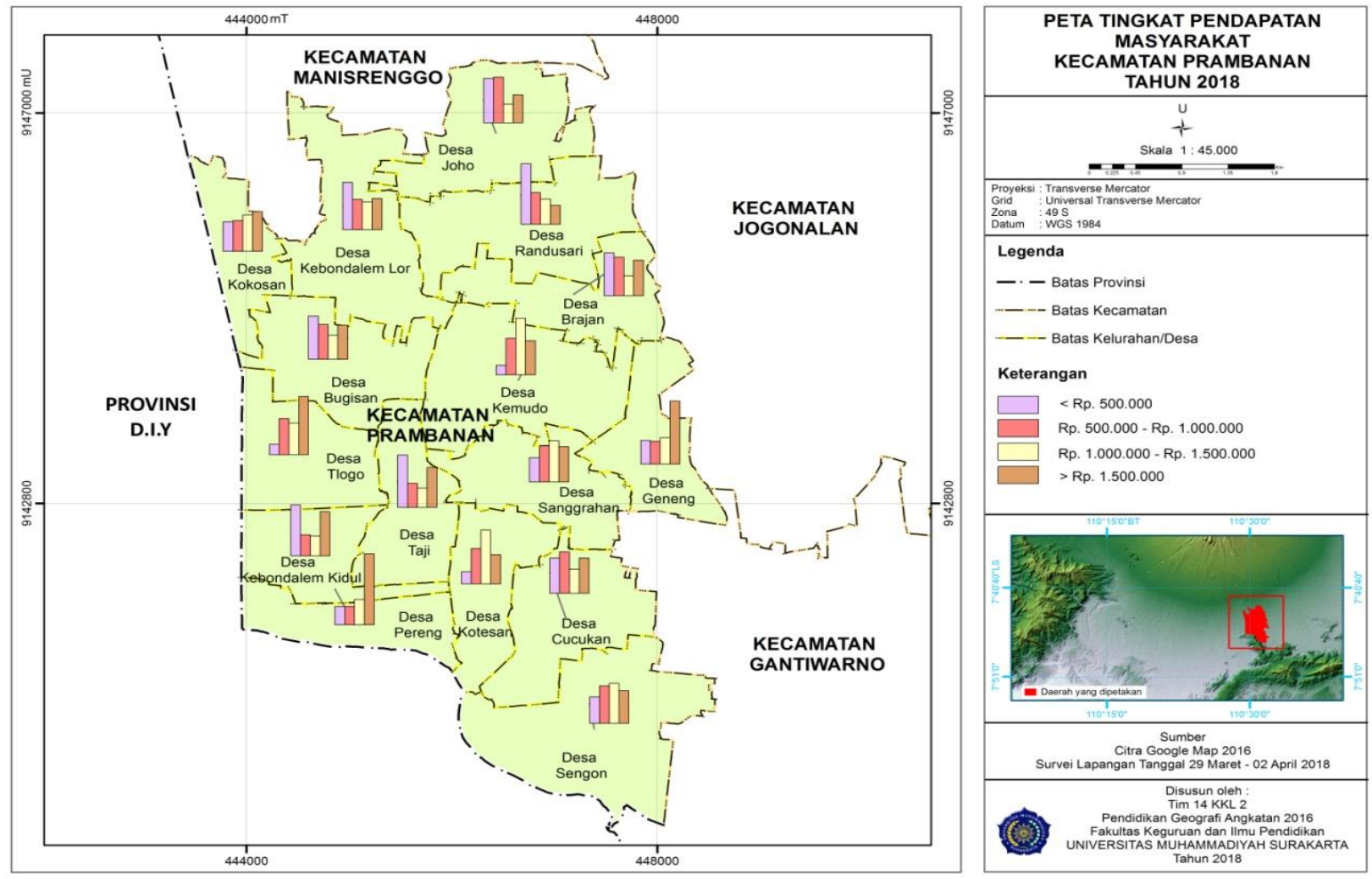

Figure 3.8Map of Level income

Source: Researcher, 2018 


\section{Conclusion}

Pereng Village is a Village with high average income, but the health condition in Pereng Village is included in the Medium category.Randusari Village is a Village with low average income, but Randusari Village health condition is included in the Medium category.Thus, it can be concluded that there is no relationship between income and health because high income is not necessarily the condition or condition in the region is high.

\section{References}

Alviana, Hendika. 2017. The Development of the Economic Potential of the Local Areas to Reduce the Gap in Growth between Subdistrict in Sukoharjo Regency years 20102015. [Article Scientific Publications]. Surakarta: Muhammadiyah University Of Surakarta

Atmawikarta, Arum. (2009). "A health Investment For economic development". BAPPENAS: Director of Community Health and Nutrition

BPS Klaten Regency. (2016). Human development Index Klaten 2016. Klaten Regency and Klaten: BPS/BPS-Statistics of Klaten Regency.

BPS Klaten Regency. (2016). Sub Prambanan in Number 2016. Klaten Regency and Klaten: BPS/BPS-Statistics of Klaten Regency.

Fadhilah, Achmad. Spatial Analysis of the Level of Insecurity Dengue Feverfor Priority Handling System Using geographical InfromasiPrambanan Sub-district Klaten Regency. Analysis of the Spatial Level, 295-305.

Hartono, Budiantoro. (2008). Analysis of the Imbalance of Economic Development in the Province of Central Java. [Thesis]. Semarang: University of Diponegoro

Klaten Regency. (2015). Community Health Profile Klaten 2015. Head Of Department: Klaten Regency.

Ismail M. (2013).The Influence of Family Income Level, Education Level of the Mother and the Mother's Employment Status for Nutritional Status in the District of Darul Makmur, Nagan Raya Regency [Thesis]. University Of Teuku Umar.

Muta'ali, Lutfi. 2015. The Regional Analysis Techniques for Planning regions, Spatial, and Environment. Yogyakarta: Faculty Of Geography Gadjah Mada University, Publisher. 
Putra, Andi NepiErtanta. (2012). Economic Growth Imbalances between Klaten Regency in Central Java province Year 1999 - 2009 [Thesis]. Yogyakarta: Atma Jaya University of Yogyakarta

Sudarlan. (2015). Economic Growth, Inequality, and Poverty in Indonesia. Journal Exists, Vol $11(1), 3036-3213$

Susilo, Abdi. (2017). Analysis of Economic Growth and Inequality of Income Distribution between the Central Java Regency [Thesis]. Surakarta: Muhammadiyah University Of Surakarta.

Syamsurijal. (2008). The Influence of the Level of Health of the Revenue capita Growth Rate Against in South Sumatra. Journal of Economics and Development Policy, Vo1 6 (1), $1-9$.

Wisana, I Dewa Gede Karma. (January 2001). Health as an Investment. Journal of Economics and the Development of Indonesia, vol. 1 (1), 42-51.

Yuhendri. (2013). Influence the Quality of Education, Health, and Investment towards Growth of West Sumatra[Article Publication]. Padang: State University of Padang

Yuliartika, Febriyana Niken., Larasati, Dheya Amalia., Sehan, Septia Mahadeka Putri., Okctaviana, Angel., Alfredo, Septian Briantama., (2017). Study of the Level of Knowledge of Early Warning Systems Individual and Household in the Face of Devastating Earthquake in Wonogiri. Presented at the National Seminar on Geography UMS 2017, Surakarta, Central Java, May 22, 2017 